\title{
EVALUATING PERFORMANCE OF THREE RABBIT GENOTYPES UNDER EGYPTIAN CONDITIONS
}

\author{
Ashour, A. F., Yaser K. Badwi and Ragaa E. Abd El-Karim \\ Animal Production Res. Inst., Agric. Res. Center, Ministry of Agric., \\ Dokki, Egypt
}

\begin{abstract}
This study was conducted for evaluation of three rabbit genotypes under Egyptian condition. First, Animal Production Research Institute (APRI), second, New-Zealand White (NZW), and third, Baladi Black (BB). Rabbits in all breeds were kept under similar managerial system and environmental conditions. Results showed that total litter size and alive born were higher $(P<0.05)$ in $A P R I$ than in NZW and BB rabbit. Mean weight of pup at birth in APRI and NZW was higher $(P<0.05)$ than $B B$ rabbits, being 51.37 and 51.42 vs. $48.22 \mathrm{~g}$, respectively. Weight at weaning of APRI and NZW exceed $(P<0.05)$ than of $B B(506.8$ and 502.4 vs $447.014 \mathrm{~g}$, respectively). The viability rate at birth was lower $(P<0.05)$ in $A P R I$ rabbit than NZW and BB, while at 12 days was lower than in NZW, followed by BB rabbit. At weaning, the viability rate was higher $(P<0.05)$ in $A P R I$ and NZW than in BB ( 75.43 and 78.38 vs $69.05 \%$, respectively). Litter size at birth was higher $(P<0.05)$ for does having 10 teats $(8.69)$ than in those with 8 and 6 teats $(6.61$ and 5.25$)$, while does having 8 teats showed higher $(P$ $<0.05)$ either size than these with 6 teats. Kit birth weight was higher ( $P$ $<0.05$ ) for does having 6 teats $(53 \mathrm{~g})$ than in those with 8 and 10 teats (50 and $47 \mathrm{~g}$ ), respectively. Milk yield from BB rabbits was significantly more $(113.8 \mathrm{~g})$ than from APRI $(98.68 \mathrm{~g})$ and NZW (91.15g). Milk yield for does having 10 teats was significantly $(106.29 \mathrm{~g})$ more than does having 8 $(98.64 \mathrm{~g})$ and 6 teats $(95.69 \mathrm{~g})$. Percentage, of fat and total solid (TS) in milk was higher $(\mathrm{P}<0.05)$ in $\mathrm{APRI}(16.85 \%$ and $36.89 \%)$, NZW $(15.96 \%$ and $36.15 \%)$ than in BB $(14.17 \%$ and $33.32 \%)$, respectively. The percentage of protein was higher $(\mathrm{P}<0.05)$ in $\mathrm{APRI}$ rabbit $(15.88 \%)$ than other breed followed by NZW (15.28\%) and BB (14.14\%).

Does rabbit having purple vulva color showed highest $(P<0.05)$ conception rate as compared as other vulva colors. White vulva color showed lower $(\mathrm{P}<0.05)$ litter size than other vulva color, while no significant differences between purple and red (7.75 and 8.01) were observed, but it was higher $(P<0.05)$ than in does with vulva pink (7.23). Gestation period (day) in BB rabbit was higher $(\mathrm{P}<0.05)$ with white vulva color than pink, red and purple (32.61, 31.76, 31.64 and 31.60), respectively.
\end{abstract}

Keywords: Rabbit, litter size, litter weight, vulva color, teat numbers, conception rate, milk production

\section{INTRODUCTION}

With increasing the human population especially in developing country like Egypt, the supply of enough animal protein from the 
principal livestock species (cattle, sheep and goats) had become difficult. Hence, the interest in micro livestock such as rabbit and poultry become the solution, because its production has enormous potential in alleviating the problem of animal protein supply in developing economy (Biobaku and Dosunmu, 2003, Fayeye and Ayorinde, 2003).

The important attributes of rabbits as micro livestock include small body size, short generation interval, ability to utilize less competitive feeds, rapid growth, potentials for genetic improvement and production of high quality meat and useful by-products (Egbo et al., 2001; Herbert, 2011). Apart from high temperature usually above $30^{\circ} \mathrm{C}$ which may impose undue stress on the animal, rabbit production can significantly contribute to man's need at all times (Tuma et al., 2010). Rabbits are characterized by high production traits, such as high fertility and prolificacy, early puberty and high growth rate of young, good feed efficiency, high dressing percentage and good meat quality (Kowalska, 2006; Zotte, 2002).

The production efficiency of commercial rabbit farms is largely dependent on the litter size at kidding and the survivability of the bunnies up to weaning (Odeyinka et al., 2008). In addition, the preweaning growth is very critical in meat rabbits due to its impact on the meat produced at the finisher stage of production (Gerencser et al., 2011). As production directly of rabbits depend on reproduction and becomes an important aspect in determining the profitability of commercial rabbit breeding. Factors such as breed, season, age, and weight of females (Lazzaroni et al., 2012 and Khalil and Al-Saef, 2012). High conception rate, high receptivity, high prolificacy, high weaning weight, large litter size and little or no mortality are the primary focus of rabbit producers for profitable rabbit production (Theilgaard et al., 2009 and Zotte and Szendro, 2011).

Selection toward does with large litters and high milk production is inefficient because of the negative aspects of such increases including the high energy deficit, fertility reduction, high doe replacement rate and mortality rate of the kids. Probably selection for higher feed intake should give animals more balanced and adapted to the actual rearing conditions. In fact some authors (Parigi-Bini and Xiccato, 1998; Xiccato et al., 1998 and Pascual et al., 1999) have shown that with does of the current hybrid the reduction of the energy deficit by nutritional strategies is not yet possible, since a high energy intake causes a simultaneous increase in milk output. In this respect, Fayeye and Ayorinde (2010) showed that selection of replacement does may not be done with accuracy using external characteristics like doe number of teats. It may also be 
possible to undertake an all year round breeding in commercial rabbit, under tropical condition.

The aim of this work was to evaluate three strains of rabbits under Egyptian conditions.

\section{Data:}

\section{MATERIALS AND METHODS}

This study was carried out at the Rabbits Farm of Sakha Station, Animal Production Research Institute, Agriculture Research Center, Egypt. Three different genetic groups of rabbit were used in this study, including, Animal Production Research Institute (APRI) ( $n=66$ does), Egyptian line synthetic for litter weight at weaning according to Abou Khadiga et al. (2010); New-Zealand White (NZW) ( $n=79$ does), foreign rabbit breed actually originated in the United States and wide spread overall the world and Baladi Black (BB) $(n=89)$, Egyptian local strains that, after their formation, have not followed by a program of genetic improvement (Khalil, 2002b).

Rabbits were housed separately in individual wired cages (30 x $50 \times 30 \mathrm{~cm}$ ) and arranged in double tier batteries allocated in two rows. All cages were equipped with feeders (made of galvanized steel sheets) and nipples (automatic drinkers). The system provides animals with fresh water. Rabbits in all breeds were kept under similar managerial system and environmental conditions.

Traits were recorded individually for each animal in each genotype group. These traits were vulva color at mating, gestation period and litter size and weight at birth, 21 day and weaning (28 days), Does were presented to the males 10 days after parturition. Ten days after mating, the does were tested for pregnancy by abdominal palpation. Non-pregnant rabbit does were re-mated. Percentage of viability at birth, 21 day and weaning were calculated.

Milk samples were taken from each breed to determine the milk composition using Milkoscan (Model 133B). Kits were separated from their mothers to prevent suckling for a period of 24 hours before samples collection in the morning. Milk yield was determined by the differences in life body weight (LBW) before and after suckling during 7 days (first week) of lactation as well as number of teat per doe were recorded in each breed.

\section{Data analysis:}

Data concerning effect of rabbit breed and number of teats on litter size, litter birth weight, and milk yield as following model (1):

$$
Y_{i j k}=\mu+B_{i}+T_{j}+\left(B^{\star} T\right)_{i j}+e_{i j k} \text {. }
$$

Where, $Y_{i j k}=$ an observation, $\mu=$ overall mean, $B_{i}=$ effect of breed, $T_{j}=$ effect of number of teats, $\left(B^{\star} T\right)_{i j}=$ interaction between breed and number of teats and $e_{i j k}=$ random error. 
However, the effect of breed and color of vulva on conception rate, litter size and pregnancy period using SPSS programme (2008) as following model (2):

$Y_{i j k}=\mu+B_{i}+V_{j}+\left(B^{*} V_{i j}+e_{i j k}\right.$.

Where, $Y_{i k}=$ an observation, $\mu=$ overall mean, $B_{i}=$ effect of breed, $V_{i}=$ effect of vulva color, $\left(\mathrm{B}^{*} \mathrm{~V}\right)_{\mathrm{ij}}=$ interaction between breed and vulva color and eijk = random error.

Differences among means were subjected to Duncan's Multiple Range-test (Duncan, 1955).

\section{RESULTS AND DISCUSSION}

Results showed significant differences for all studied traits among the three genotypes, except the litter weight at 21 day (Table 1). Analysis of variance showed that, total litter size and alive born in was significantly $(P<0.05)$ higher in APRI than in NZW and BB rabbit breeds, On the other hand, the litter size at 21 days and weaning were significantly $(P<0.05)$ higher in APRI strain and NZW than in BB local rabbit breed (Table 1). As shown in table (1), the mean weight of pup at birth and weaning in APRI and NZW were significantly $(P<0.05)$ higher than in BB rabbits, While at 21 days, no significant differences were recorded among rabbit breeds. Mean of total litter weight at birth, 21 days and weaning in BB was significant $(P<0.05)$ lower than in APRI and NZW rabbits. The viability rate at birth was significantly $(\mathrm{P}<0.05)$ lower in APRI rabbit than in NZW and BB, while at 12 days was lower than in NZW followed by BB rabbit. At weaning, the viability rate was significantly $(P<0.05)$ higher in $A P R I$ and NZW than in BB.

The low heritability coefficient $\left(h^{2}\right)$ values for litter weight traits from birth up to weaning were low $(<0.20)$, as estimated by many authors (Enab et al., 2000; Rastogi et al., 2000; Khalil et al., 2002; El-Deghadi, 2005), so, environmental factors having strong influence on these traits should be taken in consideration. The birth weight of a kit is greatly affected by genotype of both the dam and the kit itself. Moreover, the consequent litters weights are basically depend on the suckled milk from the dam; beside the kit genotype (Szendro and Maertens, 2001). Several investigators found that litter weight traits were significantly affected by breed (Cifre et al., 1996; Nofal et al., 1996; Khalil and Afifi, 2000; Abou Khadiga, 2004 and Abou Khadiga et al., 2010). In this respect, Theilgaard et al. (2009) suggested that selection for litter size could increase the reproductive sensitivity when environmental conditions limit the availability of resources. 
Table (1): Mean and level of significance differences for litter traits in three rabbit breeds

\begin{tabular}{|c|c|c|c|}
\hline Parameters & APRI & NZW & BB \\
\hline \multicolumn{4}{|l|}{ Litter size $(n)$ : } \\
\hline Total at birth $(\mathrm{n})$ & $7.71 \pm 0.24^{\mathrm{a}}$ & $6.58 \pm 0.16^{b}$ & $6.26 \pm 0.19^{b}$ \\
\hline Alive $(n)$ at birth & $7.05 \pm 0.23^{\mathrm{a}}$ & $6.38 \pm 0.15^{b}$ & $5.99 \pm 1.9^{b}$ \\
\hline At 21 days $(n)$ & $5.42 \pm 0.16^{\mathrm{a}}$ & $5.53 \pm 0.17^{\mathrm{a}}$ & $4.78 \pm 0.16^{b}$ \\
\hline At weaning $(n)$ & $5.11 \pm 0.15^{\mathrm{a}}$ & $4.96 \pm 0.17^{\mathrm{a}}$ & $3.99 \pm 0.13^{b}$ \\
\hline \multicolumn{4}{|l|}{ Litter weight $(\mathrm{g})$ : } \\
\hline At birth / kit & $51.37 \pm 0.45^{\mathrm{a}}$ & $51.42 \pm 0.71^{a}$ & $48.22 \pm 0.26^{b}$ \\
\hline Total at birth & $357.9 \pm 9.9^{a}$ & $323.9 \pm 7.1^{b}$ & $286.99 \pm 8.61^{c}$ \\
\hline At 21 days / kit & $275.1 \pm 6.44$ & $255.0 \pm 2.47$ & $249.8 \pm 3.83$ \\
\hline Total at 21 days & $1379.4 \pm 45.81^{\mathrm{a}}$ & $1409.3 \pm 44.21^{a}$ & $1162.9 \pm 31.86^{b}$ \\
\hline At weaning / kit & $506.8 \pm 10.36^{a}$ & $502.5 \pm 8.43^{a}$ & $447.01 \pm 7.57^{b}$ \\
\hline Total at weaning $(\mathrm{g})$ & $2582.7 \pm 87.76^{a}$ & $2460.8 \pm 78.97^{a}$ & $1770.18 \pm 58.94^{b}$ \\
\hline \multicolumn{4}{|l|}{ Viability (\%): } \\
\hline At birth & $92.1 \pm 12.6^{b}$ & $97.45 \pm 8.1^{\mathrm{a}}$ & $96.86 \pm 12.9^{a}$ \\
\hline At 21 days & $79.63 \pm 2.1^{b}$ & $86.87 \pm 1.64^{a}$ & $81.76 \pm 1.82^{\mathrm{ab}}$ \\
\hline At weaning & $75.43 \pm 2.13^{\mathrm{a}}$ & $78.38 \pm 2.1^{a}$ & $69.05 \pm 1.95^{b}$ \\
\hline
\end{tabular}

$a, b$, and $c$ : Means denoted within the same row with different superscripts are significantly different at $\mathrm{P}<0.05$.

Table (2): Effect of teats numbers of does on litter size and kit weight at birth and milk yield in three rabbit breeds

\begin{tabular}{|c|c|c|c|c|}
\hline \multirow{2}{*}{ Breed } & \multicolumn{3}{|c|}{ Number of teats } & \multirow{2}{*}{ Overall mean } \\
\cline { 2 - 5 } & 6 & 8 & 10 & \\
\hline Litter size at birth (n): & $6.3 \pm 0.33$ & $7.14 \pm 0.18$ & $9.7 \pm 0.24$ & $7.71 \pm 0.15^{\mathrm{A}}$ \\
\hline APRI & $5.14 \pm 0.28$ & $6.44 \pm 0.16$ & $8.17 \pm 0.22$ & $6.58 \pm 0.13^{\mathrm{B}}$ \\
\hline NZW & $4.29 \pm 0.22$ & $6.26 \pm 0.17$ & $8.22 \pm 0.2$ & $6.26 \pm 0.12^{\mathrm{B}}$ \\
\hline BB & $5.25 \pm 0.16^{\mathrm{C}}$ & $6.61 \pm 0.1^{\mathrm{b}}$ & $8.69 \pm 0.13^{\mathrm{a}}$ & - \\
\hline Overall mean & $54.62 \pm 1.1$ & $52.1 \pm 0.58$ & $47.44 \pm 0.78$ & $51.37 \pm 0.49^{\mathrm{A}}$ \\
\hline Litter birth weight (g): & $55.9 \pm 0.93$ & $50.42 \pm 0.54$ & $47.95 \pm 0.71$ & $51.42 \pm 0.43^{\mathrm{A}}$ \\
\hline APRI & $49.63 \pm 0.71$ & $48.0 \pm 0.57$ & $47.04 \pm 0.67$ & $48.22 \pm 0.38^{\mathrm{B}}$ \\
\hline NZW & $53.38 \pm 0.54^{\mathrm{a}}$ & $50.16 \pm 0.33^{\mathrm{b}}$ & $47.48 \pm 0.42^{\mathrm{C}}$ & - \\
\hline BB & \multicolumn{5}{|l}{} \\
\hline Overall & $90.0 \pm 2.02$ & $97.78 \pm 1.06$ & $108.25 \pm 1.43$ & $98.68 \pm 0.9^{\mathrm{B}}$ \\
\hline Milk yield (g): & $85.0 \pm 1.7$ & $85.12 \pm 0.99$ & $103.33 \pm 1.3$ & $91.15 \pm 0.79^{\mathrm{C}}$ \\
\hline APRI & $112.08 \pm 1.3$ & $113.03 \pm 1.03$ & $116.29 \pm 1.23$ & $113.8 \pm 0.69^{\mathrm{A}}$ \\
\hline NZW & $95.69 \pm 0.98^{\mathrm{b}}$ & $98.64 \pm 0.6^{\mathrm{b}}$ & $109.29 \pm 0.79^{\mathrm{a}}$ & - \\
\hline BB & Overall mean &
\end{tabular}

$a$, and $b$ : Means denoted within the same column with different superscripts are significantly different at $\mathrm{P}<0.05$

$A$ and $B$ Means denoted within the same column with different superscripts are significantly different at $\mathrm{P}<0.05$

Analysis of variance showed that litter size at birth was significantly higher $(P<0.05)$ in does having 10 teats $(8.69)$ than in those with 8 and 6 teats (6.61 and 5.25). Also, does having 8 teats showed significantly $(\mathrm{P}<0.05)$ higher litter size at birth than doe with 6 teats (Table 2 ).

The effect of interaction between breed and number of teats on litter size was significant $(\mathrm{P}<0.05)$. The present results showed 
the highest litter size (9.7) in APRI rabbit having 10 teats and the lowest (4.29) in BB rabbit having 6 teats number (Table 2).

Kit birth weight was significantly $(P<0.05)$ higher for doe having 6 teats $(53 \mathrm{~g})$ than in those with 8 and 10 teats $(50$ and $47 \mathrm{~g})$. Also, does having 8 teats showed significantly $(P<0.05)$ higher kit birth weight than doe with 10 teats (Table 2).

The effect of interaction between breed and number of teats on kit birth weight was significant $(P<0.05)$. The highest kit birth weight was (54g) in APRI and NZW rabbits having 6 teats and the lowest (4.29) in BB rabbit having 10 teats. Milk yield from BB rabbit was significantly $(P<0.05)$ higher $(113.8 \mathrm{~g})$ than from APRI $(98.68 \mathrm{~g})$ and NZW (91.15g). However, milk yield was affected significantly $(P<0.05)$ by teat number of does. Results in this study showed that milk yield from doe having 10 teats was significantly $(P<0.05)$ higher $(106.29 \mathrm{~g})$ than those having 8 (98.64) and 6 teats $(95.69 \mathrm{~g})$. Breed difference in milk yield was reported by some investigation. The milking ability of Giza White does is low compared to exotic breeds raised in Egypt (Ibrahim, 1985; Khalil, 1994). Although, Giza White breed is more adapted to the Egyptian conditions, the low post-natal maternal ability in such a breed (due to lower milking and suckling abilities) may be the main limiting factor for the full use of such genetic potentiality on a large scale of commercial production. Components of milk for Giza White rabbits are richer than components of milk in standard breeds raised in Egypt (Ibrahim, 1985).

Several authors (Afifi, 1971; Khalil, 1980; Emara, 1982; Khalil et al., 1987a, b; Afifi and Khalil, 1989) revealed that Giza White showed, in general, lower performance than acclimatized exotic breeds (e.g., Bouscat, Chinchilla, White Giant Flander, Grey Giant Flander) for different productive traits. The effect of interaction between breed and number of teat on milk yield was significant $(P<0.05)$. The highest milk yield was recorded $(116.29 \mathrm{~g})$ in BB rabbit having 10 teats and the lowest $(85 \mathrm{~g})$ was in NZW rabbit having 6 teats. In general the present trend of litter size and milk yield showed an increase by increasing the numbers of teats, however, kit weight showed an opposite trend (Table 1). The present result disagreed with Fayeye and Ayorinde (2010) who found that, the differences were not significant $(P<0.05)$ in litter size at birth and mean kit birth weight for does having 8,9 and 10 teats, respectively. According to these findings, selection criteria could be the teat number and growth rate. There are 8,9 or 10 teats on most of the rabbits independently of their sex (female or male). This is a highly heritable anatomical trait correlated with some low heritable reproductive performances such as litter size or suckling mortality. They can be counted on 
newborn rabbits (Szendrö, 2008, Gacek, 2010 and Castellini et al., 2010).

From the mating of parents both having 8 or 10 teats, 6 or $40 \%$ of the progenies had 10 teats, respectively (Szendrö et al., 1992). The distribution of progenies with $7,8,9,10$ or 11 teats was significantly different which confirmed the high heritability of teats numbers. Szendrő (2008) showed that rabbit does having 10 teats kindle significantly more kits per litter which have better survival up to 21 days of age than those with 8 teats. Increasing the teat number on does leads to better reproductive and rearing performance. He added that litter size increased from 8.04 to 8.55 due to the selection for teat number. These results proved that simultaneous selection for teat number and weight gain could be a good approach in mediumsized farms. Teat number is not connected with milk production. It seems that the mammary gland (milk yield) has the same size of does with different teat numbers but kits have more chance to catch a teat during the short nursing time. Despite of similar milk production, their chance to suck some milk is higher in case of 10 teats and it is suggested that to mark and select female and male newborn rabbits with 10 teats to improve the productivity (Szendrö, 2008).

The survival rate of kits is in close correlation with their birth weight and milk supply. With increasing litter size the average birth weight of kits decreases and the proportion of new-born rabbits with very low weight increases. The short nursing time reduces the chance of nursing all of the kits if the litter size is higher than the number of teats. In the competition for reaching a teat, the weakest kits lose (Szendrö, 2008). Also, it was found that all kits weighing 25$30 \mathrm{~g}$ at birth and half of them weighing $35-45 \mathrm{~g}$ died during the first week of their life (Szendrő and Barna, 1984).

\section{Receptivity}

Effect of receptivity (vulva color) on some reproductive performance and litter size in three genotypes rabbit under Egyptian condition is presented in table 3 . Vulva color significantly $(P<0.05)$ affected on conception rate, litter size and pregnancy period.

Doe rabbits having purple vulva color showed significantly $(P<0.05)$ the highest conception rate compared to other vulva colors but no significant differences were observed between pink and red vulva color while, white vulva showed the lowest conception rate (Table 3). 
Table (3): Effect of receptivity (vulva color) on conception rate, Litter size alive and pregnancy period in three rabbit breeds

\begin{tabular}{|c|c|c|c|c|c|}
\hline \multirow{2}{*}{ Breed } & \multicolumn{4}{|c|}{ Vulva color } & \multirow{2}{*}{$\begin{array}{c}\text { Overall } \\
\text { mean }\end{array}$} \\
\hline & White & Pink & Red & Purple & \\
\hline \multicolumn{6}{|c|}{ Conception rate (\%) } \\
\hline APRI & $32.14 \pm 7.59$ & $70.59 \pm 9.74$ & $75.0 \pm 6.35$ & $90.0 \pm 3.67$ & $66.93 \pm 3.59$ \\
\hline NZW & $26.32 \pm 9.21$ & $64.0 \pm 8.03$ & $76.92 \pm 6.79$ & $81.61 \pm 4.31$ & $62.21 \pm 3.79$ \\
\hline BB & $21.43 \pm 10.73$ & $66.67 \pm 10.37$ & $65.71 \pm 13.1$ & $82.47 \pm 3.76$ & $59.1 \pm 4.2$ \\
\hline Overall mean & $26.63 \pm 5.35^{c}$ & $67.1 \pm 5.45^{\mathrm{b}}$ & $72.55 \pm 4.1^{b}$ & $84.69 \pm 2.26^{a}$ & - \\
\hline \multicolumn{6}{|l|}{ Litter size (n) } \\
\hline APRI & $5.43 \pm 0.5$ & $8.0 \pm 0.44$ & $8.56 \pm 0.33$ & $8.85 \pm 0.14$ & $7.71 \pm 0.19^{\mathrm{a}}$ \\
\hline NZW & $4.25 \pm 0.66$ & $6.69 \pm 0.37$ & $8.0 \pm 0.37$ & $7.38 \pm 0.17$ & $6.58 \pm 0.21^{b}$ \\
\hline BB & $3.50 \pm 0.93$ & $7.0 \pm 0.47$ & $7.46 \pm 0.37$ & $7.03 \pm 0.15$ & $6.26 \pm 0.28^{b}$ \\
\hline Overall mean & $4.39 \pm 0.42^{\mathrm{C}}$ & $7.23 \pm 0.25^{b}$ & $8.01 \pm 0.20^{\mathrm{a}}$ & $7.75 \pm 0.09^{\mathrm{a}}$ & - \\
\hline \multicolumn{6}{|c|}{ Pregnancy period (day) } \\
\hline APRI & $32.57 \pm 0.47$ & $31.67 \pm 0.41$ & $31.69 \pm 0.31$ & $31.63 \pm 0.13$ & $31.89 \pm 0.18$ \\
\hline NZW & $32.25 \pm 0.62$ & $31.62 \pm 0.34$ & $31.54 \pm 0.34$ & $31.77 \pm 0.16$ & $31.79 \pm 0.2$ \\
\hline BB & $33.00 \pm 0.87$ & $32.0 \pm 0.44$ & $31.69 \pm 0.34$ & $31.40 \pm 0.14$ & $32.02 \pm 0.26$ \\
\hline Overall mean & $32.61 \pm 0.39^{a}$ & $31.76 \pm 0.23^{b}$ & $31.64 \pm 0.19^{b}$ & $31.6 \pm 0.82^{b}$ & - \\
\hline
\end{tabular}

$a, b, c$ and $d$ : Means denoted within the same row or column with different superscripts are significantly different at $\mathrm{P}<0.05$

On the other hand, there was no significant differences among three genotypes in overall conception rate, whoever the high conception rate was found in APRI (66.93\%) followed by NZW $(62.21 \%)$ and BB (59.1\%) (Table 3).

White vulva color significantly $(P<0.05)$ decreased litter size as compared other vulva color, while no significant differences between purple and red, being significantly $(P<0.05)$ higher than in doe with vulva pink.

Pregnancy period (Table 3) in BB rabbit was significantly longer with white vulva color than pink, red and purple. On the other hand, there were no significant differences among three genotypes in pregnancy period. The effect of interaction between breed and vulva color on conception rate, litter size and pregnancy period were not significant (Table 3). Rabbit is sexually receptive if her vulva is turgid and reddish or purple (Rodriguez and Ubilla, 1988). Receptivity is a strong indicator of fertility. This is why the main aim is to increase receptivity at the time of insemination by hormonal (PMSG) treatment (Maertens et al., 1995) or by biostimulation (Theau-Clement, 2000). Szendrö et al., (2006) showed a significant effect of vulva color on reproductive performance using natural mating. In case of artificial insemination $(\mathrm{Al})$, the conception rate mainly depends on vulva turgidity but the litter size relies on vulva color (reddish). The best results (number of kits/AI) were achieved when the vulva was turgid and red or violet (Szendrő, 2008 and Szendrő et al., (2012)). 


\section{Milk composition:}

Milk composition of three genotypes does including the percentages of fat, protein, lactose, total solids (TS), solids not fat (SNF) and ash is presented in Table (4).

Table (4): Milk composition during $7^{\text {th }}$ day post-partum in three rabbit breeds

\begin{tabular}{|l|c|c|c|}
\hline Parameters & APRI & NZW & BB \\
\hline Fat (\%) & $16.85 \pm 0.16^{\mathrm{A}}$ & $15.96 \pm 0.50^{\mathrm{A}}$ & $14.17 \pm 0.13^{\mathrm{B}}$ \\
\hline Protein (\%) & $15.88 \pm 0.40^{\mathrm{A}}$ & $15.28 \pm 0.24^{\mathrm{AB}}$ & $14.14 \pm 0.48^{\mathrm{B}}$ \\
\hline Lactose (\%) & $2.24 \pm 0.04$ & $2.59 \pm 0.17$ & $2.67 \pm 0.31$ \\
\hline Total solids (TS) (\%) & $36.89 \pm 0.16^{\mathrm{A}}$ & $36.15 \pm 0.53^{\mathrm{A}}$ & $33.32 \pm 1.1^{\mathrm{B}}$ \\
\hline Solids not fat (\%) & $20.04 \pm 0.32$ & $20.19 \pm 0.06$ & $19.14 \pm 1.04$ \\
\hline Ash (\%) & $1.91 \pm 0.39$ & $2.31 \pm 0.04$ & $2.33 \pm 0.38$ \\
\hline
\end{tabular}

$\mathrm{a}$, and $\mathrm{b}$ : Means denoted within the same row with different superscripts are significantly different at $\mathrm{P}<0.05$

The present results showed that of percentage of fat and TS was significantly $(P<0.05)$ higher in milk from APRI and NZW rabbits than in BB rabbit. While the percentage of protein was significantly $(P<0.05)$ higher in APRI rabbit than other breed followed by NZW and $\mathrm{BB}$.

EL-Nagar et al., (2012) showed differences in milk composition traits among 3 maternal rabbit lines differences and the overall percentages of fat, protein, ash, lactose and total solids were $14.62,11.10,1.89,2.67$ and 30.27, respectively.

Khalil, (2002a) reported that the components of milk (fat, protein, and lactose) were 23, 18 and 2.9\%, respectively, for Giza White rabbits being richer than components of milk in standard breeds raised in Egypt. Ibrahim (1985) reported negative correlation between the milk yield and its content of fat, protein and total solids.

Iraqi et al., (2007) found that the genetic group effect was significant for milk fat and milk total solids. The estimates of the heterosis effect ranged between 1.6 and $12.8 \%$ for production and milk gross chemical traits, being significant only for milk fat content while the heterosis was non-significant for milk mineral content traits.

Conclusion, After the general comparison of the three genetic groups, it is clear that the breeding plan put earlier succeeded in producing good efficient and adapted local strains (APRI). The results of this study suggested for future breeding plan under Egyptian conditions that the best selection strategy is to choose female rabbit having higher litter size and weight where the number of teats is 10 in order to provide kits with adequate milk supply. Before the first mating sexual receptivity can be increased with flushing (add libitum feeding of pellet with high energy, protein 
etc.). Finally, crossing different breeds in the future must be available to obtain a heterotic breed under Egyptian conditions (such as APRI).

\section{REFERENCES}

Abou Khadiga G., (2004). Performance of the Spanish synthetic V line and the local Baladi Black rabbits and their crosses of rabbits and Egyptian conditions. M. Sc. Thesis, Faculty of Agriculture, Kafr El-Sheikh, Tanta University, Egypt.

Abou Khadiga, G., Youssef, Y.M.K., Saleh, K., Nofal, R.Y. and Baselga, M., (2010). Genetic trend in selection for litter weight in two maternal lines of rabbits in Egypt. World Rabbit Sci., 18: 27-32.

Afifi, E.A. (1971). A study of some economical and productive characters in some breeds of rabbits and their crosses. PhD Thesis, Faculty of Agriculture, Ain-Shams University, Egypt.

Afifi, E.A. and Khalil, M.H. (1989). Observations on purebred and crossbred litters of Giza White and Grey Giant Flander rabbits in Egypt. Journal of Applied Rabbit Research, 12: 273-277.

Biobaku, W.O. and Dosunmu, E.O., (2003). Growth response of rabbits fed graded level of processed and un-dehulled sunflower seed. Nigerian Journal of Animal Production 30(2): 179-184.

Castellini C., Dal Bosco A., Arias-Alvarez M., Lorenzo P.L., Cardinali R., and Rebollar, P.G., (2010). The main factors affecting the reproductive performance of rabbit does: A review. Animal Sci. Reproduction, 122, 174-182.

Cifre J., Baselga M. García-Ximenez F., Vicente J.S., (1996). A study of reproductive and growth traits of a maternal rabbit line founded by selection of hyperprolific does. In: Proc. 6th World Rabbit Congress, Toulouse, France, July 9-12, 1996, Vol., 2: 265-268.

Duncan, D.B., (1955). Multiple range and multiple F test. Biometrics 11:1042.

Egbo, M.L., Doma, U.D. and Lacdacks, A.B., (2001). Characteristics of small scale rabbit production and management in Bauchi. In: Proceedings of 20th Annual Conference of Nigerian

El-Deghadi, (2005). Genetic evaluation for some productive traits in rabbits. Ph. D. Thesis, Faculty of Agriculture, Banha University, Egypt.

EL-Nagar, A.G.F., J.P. Sánchez, M.M. Ragab, C.B. Mínguez and Baselga M.I.z., (2012). Genetic comparison of milk production and composition in three maternal rabbit lines. $10^{\text {th }}$ World Rabbit Congress. Sep. 3-6, Sharm El- Sheikh, Egypt 39-51.

Emara, M.E.A., (1982). Effect of crossbreeding on some productive traits in rabbits. PhD Thesis, Faculty of Agriculture at Moshtohor, Zagazig University, Banha Branch, Egypt. 
Enab A.A., El-Weshahy O.A., Abdou F.H., (2000). Genetic analysis of some economic traits in rabbits. Egypt. J. Rabbit Sci., 102, 327339.

Fayeye, T.R. and Ayorinde, K.L., (2003). Litter growth and weaning characteristics in two generations of straightbred and crossbred rabbits. Nigerian Journal of Genetics 18: 68-72.

Fayeye, T.R. and Ayorinde K.L., (2010). Effects of Season, Generation, Number of Mating, Parity and Doe Number of Teat on Doe and Litter Birth Characteristics in Domestic Rabbit. Research Journal of Animal and Veterinary Sciences, 5: 6-9.

Gacek, L.A., (2010). Production of live rabbits. Wiadomości Zootechniczne, R. XLVIII, 2- 3: 34-40.

Gerencser Zs., Matics Zs., Nagy I., and Szendrö Zs., (2011). Effect of lighting schedule on production of rabbit does. World Rabbit Sci. 19: 209-216.

Herbert, U. (2011). Unending seeds and waters of animal life. 12th Inaugural lecture series of Michael Okpara University of Agriculture, Umudike, Nigeria, Nov. 9, pp. 1-41.

Ibrahim, F.A., (1985). Studies on some factors affecting reproduction performance, milk production and preweaning mortality in rabbits. MSc Thesis, Faculty of Agriculture, Cairo University, Egypt.

Iraqi, M.M., M.E. Shenana and Baselga, M., (2007). Some factors affecting productive and milk composition characters in a crossbreeding experiment involving Gabali and V- line rabbits in Egypt. World Rabbit Sci., 15(3), 151-159.

Khalil, M.H., (1980). Genetic and environmental studies on some productive traits in rabbits. MSc Thesis, Faculty of Agriculture at Moshtohor, Zagazig University, Egypt.

Khalil, M.H., Afifi, E.A. and Emara, M.E., (1987a). Possibility of early direct and indirect selection for doe litter performance of Bauscat and Giza White rabbits. Journal of Applied Rabbit Research, 10(2): 88-93.

Khalil, M.H., Afifi, E.A. and Owen, J.B., (1987b). A genetic analysis of body weight traits in young Bauscat and Giza White rabbits. Anim. Prod., 45: 135-144.

Khalil, M.H., (1994). Lactational performance of Giza White rabbit and its relation with preweaning littertraits. Anim. Prod., 59: 141145.

Khalil M.H. and Afifi E.A., (2000). Heterosis, maternal and direct additive effects for litter performance and postweaning growth in Gabali rabbits and their F1 crosses with New Zealand White. In: Proc. 7th World Rabbit Congress, July 4-7, 2000, Valencia, Spain, Vol. A, 431-437.

Khalil, M.H., (2002a). The Giza White Rabbits. Rabbit Genetic Resources in Mediterranean Countries. Options Mediterranennes, Series B, N. 38, 1-36 
Khalil, M.H., (2002b). The Baladi rabbits. In Khalil M.H. and M. Baselga (Eds). Rabbit Genetic Resources in Mediterranean Countries. Options Mediterranennes, Series B, N. 38, 37-50.

Khalil M.H., Al-Sobayel K., Hermes I.H., Al-Homidan A.H., (2002). Crossbreeding effects for post-weaning growth, rectal and ears temperatures and respiration rates in crossing Saudi Gabali with Spanish VLine rabbits. In: Proc. 7th World Congress on Genetics Applied to Livestock Production, 2002 August, Montpellier, France, Communication n. 04-12.

Khalil, M.H., Al-Saef, A.M., (2012). Genetic groups comparison for litter and lactational traits and feeding parameters in program of synthesizing new lines of rabbits. 10th World Rabbit Congress, 3-6 September 2012, Sharm El Sheikh Egypt. 235-239.

Kowalska D., (2006). Keeping rabbits for meat or fur production? Wiadomości Zootechniczne, R. XLIV, 2, 55-62.

Lazzaroni C., Biagini D., Redaelli V., Luzi F., (2012). Technical Note: Year, season, and parity effect on weaning performance of the Carmagnola Grey Rabbit breed. World Rabbit Sci. 20: 57-60.

Maertens L., Lozi F., and Grilli G., (1995). Effect of PMSG induced Oestrus on The Performance of Rabbit Does: A review. World Rabbit Science, 3(4), 191-199.

Nofal R.Y., Toth S., Virag G.Y., (1996). Evaluation of seven breed groups of rabbits for litter traits. In: Proc. 6th World Rabbit Congress, Toulouse, France, July 9-12, 1996, Vol. 2, 335-339.

Odeyinka S.M., Oyedele O.J., Adeleke T.O., and Odedire J.A., (2008). Reproductive performance of rabbits fed Moringa oleifera as a replacement for Centrosema pubescens. 9th World Rabbit Congress Verona-Italy, June 10-13, pp. 411-416.

Parigi Bini, R.and Xiccato, (1998). Energy metabolism and requirements. In: C. de Blas and J. Wiseman (eds), The nutrition of the rabbit CABI Publishing. Wallingford Oxon UK. Pg. 103 - 131 .

Pascual, J.J., Cervera C., Blas E., Fernandez-Carmona J., (1999). Effect of high fat diets on the performance, milk yield and milk composition of multiparous rabbit does. Anim. Sci., 68, 151162.

Rastogi, R.K., Lukefahr S.D., Lauckner F.B., (2000). Maternal heritability and repeatability for litter traits in rabbits in a humid tropical environment. Livest. Prod. Sci., 67, 123-128.

Rodriguez, J.M., and Ubilla, E., (1988). 4th World Rabbit Congr. Budapest Oct, 1988

SPSS, (2008). SPSS User's Guide Statistics. Ver.17. Copyright SPSS Inc., USA.

Szendrő, Zs., Barna, J., (1984). Some factors affecting mortality of suckling and growing rabbits. In Proceedings of the 3rd World Rabbit Congress, Rome, 166-173. 
Szendrő, Zs., Mohamed, M.M.A., Bíróné Németh, E., Radnai, I., (1992). Heritability of teat number on rabbits. J. Appl. Rabbit Res., 15. 174-180.

Szendro Zs., and Maertens L., (2001). Maternal effect during pregnancy and lactation in rabbits a review. Acta Agarica Kaposvariensis. 52, 1-21.

Szendrő, Zs., A. A. Rashwan, E. Bíró-Németh and I. Radnai. (2006). Effect of vulva color and turgidity on conception rate and litter size of rabbit does. Proc. 18th Hung. Conf. Rabbit Prod., Kaposvár, Hungary, pp. 123-126.

Szendrő, Zs., (2008). Improving of reproductive performance of rabbit does in small and medium scale rabbit farms. Recommendations for developing countries. Acta Agraria Kaposváriensis Vol 12 No 1, 1-23

Szendrő, Zs., K. Szendrő and A. Dalle Zotte., (2012). Management of Reproduction on Small, Medium and Large Rabbit Farms: A Review J. Anim. Sci. Vol. 25, No. 5: 738 - 748.

Theau-Clément, M., (2000). Advances in Biostimulation Methods Applied to Rabbit Reproduction. 4th World Rabbit Congr. Valencia Spain, Volume A, pages 61-79.

Theilgaard, P., Sánchez, J.P., Pascual, J.J., Berg, P., Friggens, N.C. and Baselga, M., (2007). Late reproductive senescence in a rabbit line hyper selected for reproductive longevity, and its association with body reserves. Genet. Sel. Evol. 39, 207-223.

Theilgaard, P., M. Baselga, E. Blas, N.C. Friggens, C. Cervera and J.J., Pascual, (2009). Differences in productive robustness in rabbits selected for reproductive longevity or litter size. The Animal Consortium, 1-10.

Tuma J., Tůmová E., and Valášek V., (2010). The effect of season and parity order on fertility of Rabbit does and kit growth. Czech J. Anim. Sci. 55 (8), 330-336.

Xiccato, G., Angela Trocino, and A. Carazzolo, (1998). Ensiling and nutritive value of kenaf (Hibiscus cannabinus). Animal Feed Science Technology 71: 229-240

Zotte A.D., (2002). Perceptron of rabbit meat quality and major factors influencing the rabbit carcass and meat quality. Livestock Production Science, 75, 11-32.

Zotte A.D., and Szendro Z. (2011). The role of rabbit meat as funcional ford. Meat Science, 319-331. 


\section{تقييم الآداء لثلاث سلالات ارانب تحت الظروف المصرية}

\section{أيمن فؤاد عبد الهادي عاشور , ياسر كامل بدوى , رجاء السيا عبد الكريم

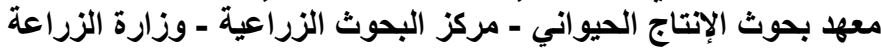

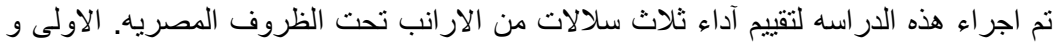

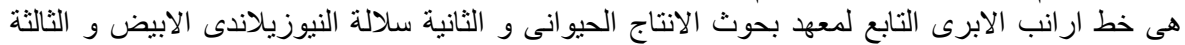

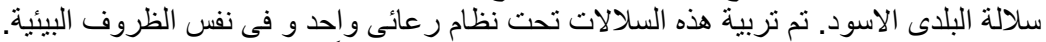

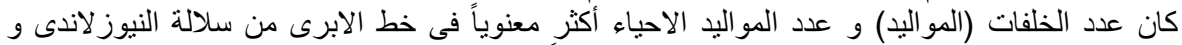

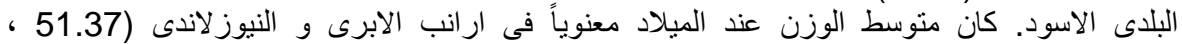

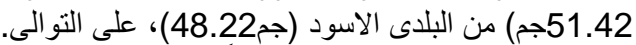

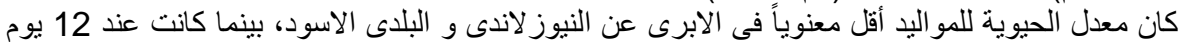

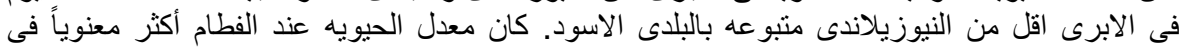

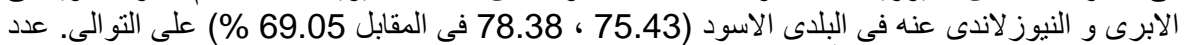

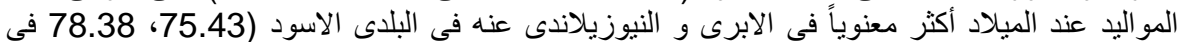

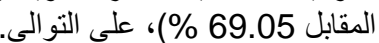

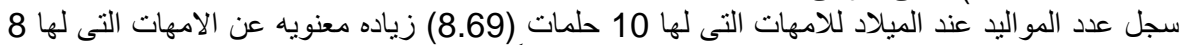

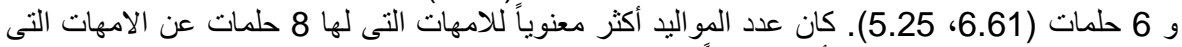

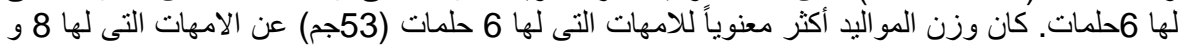

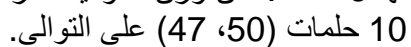

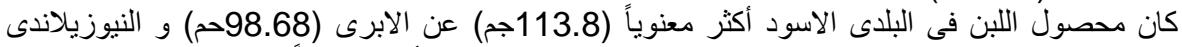

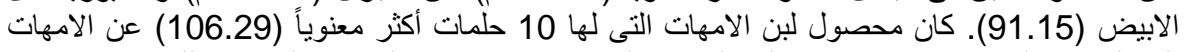

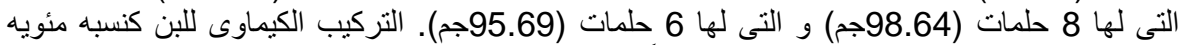

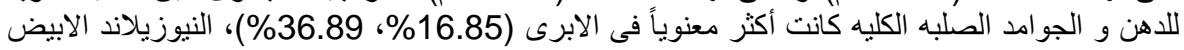

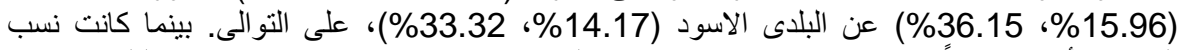
البروتين أكثر معنوياً فى الابرى (15.88\%) عن النيوزيلاندى الابيض (15.28\%) و البلدى الاسلى (\%14.14)

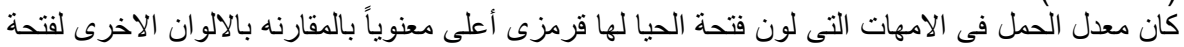

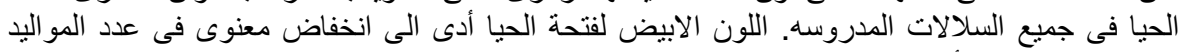

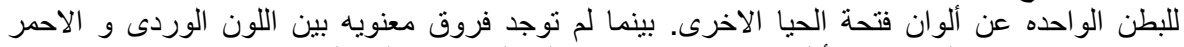

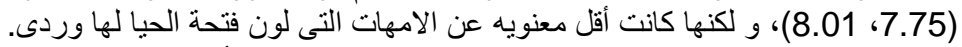

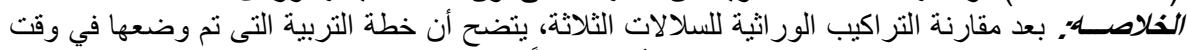

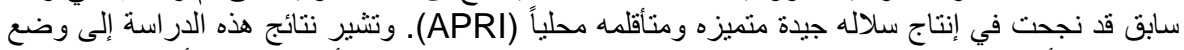

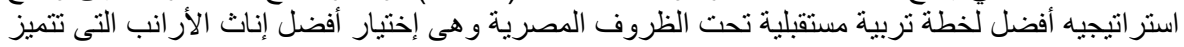

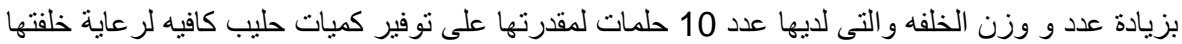

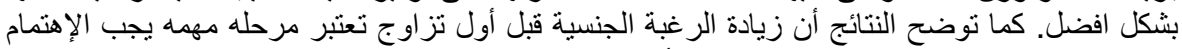

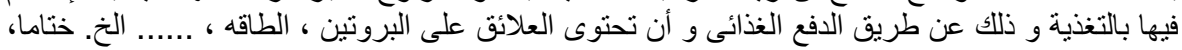

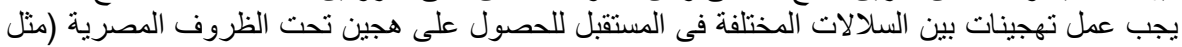

